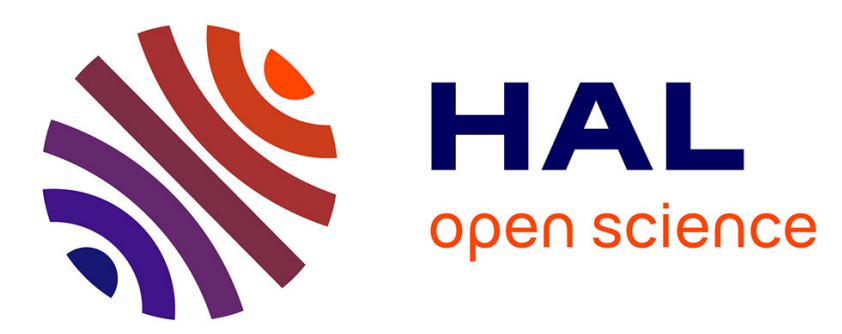

\title{
Demonstration of the "Break-and-Seal" Approach to Fullerides of Complex Cations at the Example of $\mathrm{KC60}$ (THF)5 (THF)2
}

Nina Kozhemyakina, Jürgen Nuss, Martin Jansen

\section{To cite this version:}

Nina Kozhemyakina, Jürgen Nuss, Martin Jansen. Demonstration of the "Break-and-Seal" Approach to Fullerides of Complex Cations at the Example of KC60(THF)5 (THF)2. Journal of Inorganic and General Chemistry / Zeitschrift für anorganische und allgemeine Chemie, 2009, 635 (9-10), pp.1355. 10.1002/zaac.200900283 . hal-00499558

\section{HAL Id: hal-00499558 https://hal.science/hal-00499558}

Submitted on 10 Jul 2010

HAL is a multi-disciplinary open access archive for the deposit and dissemination of scientific research documents, whether they are published or not. The documents may come from teaching and research institutions in France or abroad, or from public or private research centers.
L'archive ouverte pluridisciplinaire HAL, est destinée au dépôt et à la diffusion de documents scientifiques de niveau recherche, publiés ou non, émanant des établissements d'enseignement et de recherche français ou étrangers, des laboratoires publics ou privés. 


\section{Demonstration of the "Break-and-Seal" Approach to Fullerides of Complex Cations at the Example of $\mathrm{KC}_{60}(\mathrm{THF})_{5^{\prime}}(\mathrm{THF})_{2}$}

\begin{tabular}{|r|l|}
\hline Journal: & Zeitschrift für Anorganische und Allgemeine Chemie \\
\hline Manuscript ID: & zaac.200900283 \\
\hline Wiley - Manuscript type: & Article \\
\hline Date Submitted by the \\
Author: & $26-$ May-2009 \\
\hline Complete List of Authors: & $\begin{array}{l}\text { Kozhemyakina, Nina; Max-Planck-Institute for Solid State Research, } \\
\text { Chemistry III } \\
\text { Nuss, Jürgen; Max-Planck-Institute for Solid State Research, } \\
\text { Chemistry III } \\
\text { Jansen, Martin; Max-Planck-Institute for Solid State Research, } \\
\text { Chemistry III }\end{array}$ \\
\hline Keywords: & \begin{tabular}{l} 
Fullerenes, Synthesis design, Radical ions, Ion pairs, Crystal growth \\
\hline
\end{tabular} \\
\hline
\end{tabular}

\section{S ScholaroNE \\ Manuscript Central}




\title{
ARTICLE
}

DOI: 10.1002/zaac.200((will be filled in by the editorial staff))

\section{Demonstration of the "Break-and-Seal" Approach to Fullerides of Complex Cations at the Example of $\mathrm{KC}_{60}(\mathrm{THF})_{5} \cdot(\mathrm{THF})_{2}$}

\author{
Nina V. Kozhemyakina, ${ }^{[\mathrm{a}]}$ Jürgen Nuss, $^{[\mathrm{a}]}$ and Martin Jansen ${ }^{[\mathrm{a}] *}$
}

Keywords: Fullerenes; Synthesis design; Radical ions; Ion pairs; Crystal growth

\author{
Prof. Dr. M. Jansen \\ Fax: +49-711-689-1502 \\ E-Mail: M.Jansen@ fkf.mpg.de \\ [a] Max-Planck-Institut für Festkörperforschung \\ Heisenbergstr. 1 \\ D-70569 Stuttgart, Germany
}

Abstract. The "break-and-seal" method known to be used for synthesis of sensitive compounds (alkalides, electrides and for living anionic polymerization) was applied for the first time for fulleride synthesis providing highest purity of the reaction conditions. A new fulleride $\mathrm{KC}_{60}(\mathrm{THF})_{5} \cdot(\mathrm{THF})_{2}$ was prepared in solution by reacting fullerene $\mathrm{C}_{60}$ with potassium and dibenzo-24crown-8 in tetrahydrofurane. Single crystals were grown from solution by the modified "temperature difference method", single-

crystal X-ray analysis was performed revealing the structure $\left[P 2{ }_{1} 2{ }_{1} 2, Z=4, a=17.802(5), b=30.085(9), c=9.863(3) \AA, R_{1}\right.$ $=0.069, w R($ all $)=0.191,5563$ independent reflections $]$. In this compound, the charge of fulleride is -1 , the $\mathrm{C}_{60}{ }^{-}$radical-anion being fully ordered. A constitutive structural feature is octahedraly coordinated potassium atoms with five THF and one fulleride as ligands. $\mathrm{C}_{60}{ }^{-}$is functioning as a $\eta^{3}$-ligand: $\left[\mathrm{K}\left(\eta^{3}-\right.\right.$ $\left.\left.\mathrm{C}_{60}\right)\left(\eta^{1}-\mathrm{THF}\right)_{5}\right] \cdot(\mathrm{THF})_{2}$.

\section{Introduction}

Among the rich and multifaceted chemistry of fullerenes their redox properties are most conspicuous. While the ionization potential of e.g. $\mathrm{C}_{60}$ is rather high $\left(\mathrm{IP}_{\mathrm{C} 60}=7.58\right.$ eV) [1], and very few cationic species have been realized in a chemical environment yet [2], $\mathrm{C}_{60}$ and all other members of the fullerene family are easily reduced $\left(\mathrm{EA}_{\mathrm{C} 60}=2.65 \mathrm{eV}\right)$ [3]. A number of interesting chemical and physical phenomena can be associated to the resulting anions or radical-anions. They may dimerize [4-9], oligomerize or even polymerize [10-15], undergo a Jahn-Teller-distortion [16-18] in order to achieve a non-degenerate electronic ground state, and last but not least the unsaturated spins present can give rise to collective properties like superconductivity $[19,20]$ and ferromagnetism $[21,22]$. As a basis for any deeper understanding of the chemistry and physics of fullerides, detailed knowledge of their respective structural features is indispensable. In many instances, this requirement is not fulfilled, this is particularly true when single spherical countercations like alkali ions are involved.

Therefore, we have started to study fullerides with large complex cations, e.g. $\left[\mathrm{Ba}\left(\mathrm{NH}_{3}\right)_{7}\right] \mathrm{C}_{60} \cdot \mathrm{NH}_{3} \quad$ [18], $\left[\mathrm{Ni}\left(\mathrm{NH}_{3}\right)_{6}\right] \mathrm{C}_{60} \cdot 6 \mathrm{NH}_{3} \quad[23], \quad\left(\mathrm{BzlNMe}_{3}\right)_{2} \mathrm{C}_{60} \cdot 3 \mathrm{NH}_{3} \quad$ [24], $\left[\mathrm{M}\left(\mathrm{NH}_{3}\right)_{6}\right] \mathrm{C}_{60} \cdot 6 \mathrm{NH}_{3}\left(\mathrm{M}=\mathrm{Mn}^{2+}, \mathrm{Cd}^{2+}, \mathrm{Co}^{2+}\right.$ and $\left.\mathrm{Zn}^{2+}\right)[25$, 26] which, indeed, act as blockers fixing the fulleride in one orientation. Also using systems based on conventional organic solvents instead of somewhat capricious liquid ammonia has proven to be an efficient approach to fullerides of complex cations [27-31], even allowing first physical characterizations like measurements of the magnetic susceptibility $[27,28,30]$. Since all tools probing unpaired spins are extremely sensitive to impurities, we have regarded it desirable to warrant highest purity of the samples possible by designing a special procedure for synthesis along which any contaminations, including grease from joints, will be avoided. Our approach is inspired by a technique developed by James L. Dye for the synthesis of extremely sensitive alkalides and electrides [32-35] as well as used in "living anionic polymerization" [36] and just for the synthesis of very sensitive substances [37]. Since conventional joints need to be avoided, the glassware is composed by sealing and opened by breaking, which is reflected by calling this mode of operation "break-and-seal" technique. Here we demonstrate the feasibility of such an approach by synthesizing and growing crystals of the fulleride $\mathrm{KC}_{60}(\mathrm{THF})_{5} \cdot(\mathrm{THF})_{2}$, where $\mathrm{THF}$ stands for tetrahydrofurane. The particular combination of reducing and complexing agents has been chosen because of the high reduction power of potassium on one hand and the benzene rings attached to the crown having the potential to suppress rotational disorder of the fulleride by $\pi-\pi$ aromatic interactions on the other.

\section{Experimental Section}

All experiments were conducted in a specially designed all-glass apparatus sealed under vacuum equipped with breakseals and sealoffs (constrictions) in order to fulfil the high purity conditions required. The glassware was attached to the vacuum line and was thoroughly checked for microleakages with the high frequency spark vacuum-tester and heated under dynamic vacuum and purged with argon three times prior to each step of the experiment. The latter included: preparation of the solvents, fulleride synthesis in solution (introduction of solvent and starting materials and mixing the educts), filtering the solution and dividing into ampoules with smaller volume, and, finally, crystallization and harvesting of single crystals.

Purification of Starting Compounds. $\mathrm{C}_{60}$ fullerene (99.9\%, "MER Corporation", USA) was used as purchased. The solvents - 
tetrahydrofurane (THF) ("Carl Roth", $\geq 99.9 \%, \mathrm{H}_{2} \mathrm{O} \leq 50$ ppm) and $n$-octane ("Alfa Aesar", 98+\%) - were distilled and refluxed over sodium under argon for $3 \mathrm{~h}$, THF being additionally refluxed at first over potassium hydroxide for $3 \mathrm{~h}$. The purified solvents were degassed by the "freeze-thaw-pumping" technique, never exposed to air, distilled under vacuum and sealed into ampoules over $\mathrm{Na} / \mathrm{K}$ alloy. The crown-ether (dibenzo-24-crown-8, "Fluka", $98 \%$ ) was recrystallized from octane.

Preparation of Solvents. The sealing of solvents into ampoules is schematically shown in Figure 1. A $500 \mathrm{ml}$ flask $A$, with dried and distilled solvent, was connected through a stopcock to the vacuum line, and to an empty ampoule $B$ equipped with a breakseal and a constriction.

$\mathrm{The} \mathrm{Na} / \mathrm{K}$ alloy was prepared from pieces of metallic sodium and potassium ("Merck", cubes under protective liquid for synthesis) with 1:3 mass ratio, respectively, which after removing the oil and crust, were placed in a $50 \mathrm{ml}$ round bottom flask under argon flow. They were molten by gentle heating $\left(60-70{ }^{\circ} \mathrm{C}\right)$. The as obtained alloy was cooled to room temperature under argon flow and then transferred rapidly into the ampoule $B$ through the connection with a pipette, the latter being purged several times with argon. The solvent was condensed from $A$ by cooling $B$ with liquid nitrogen. The ampoule $B$ was sealed off at the constriction. THF over alloy got blue with time because of the generation of solvated electrons.

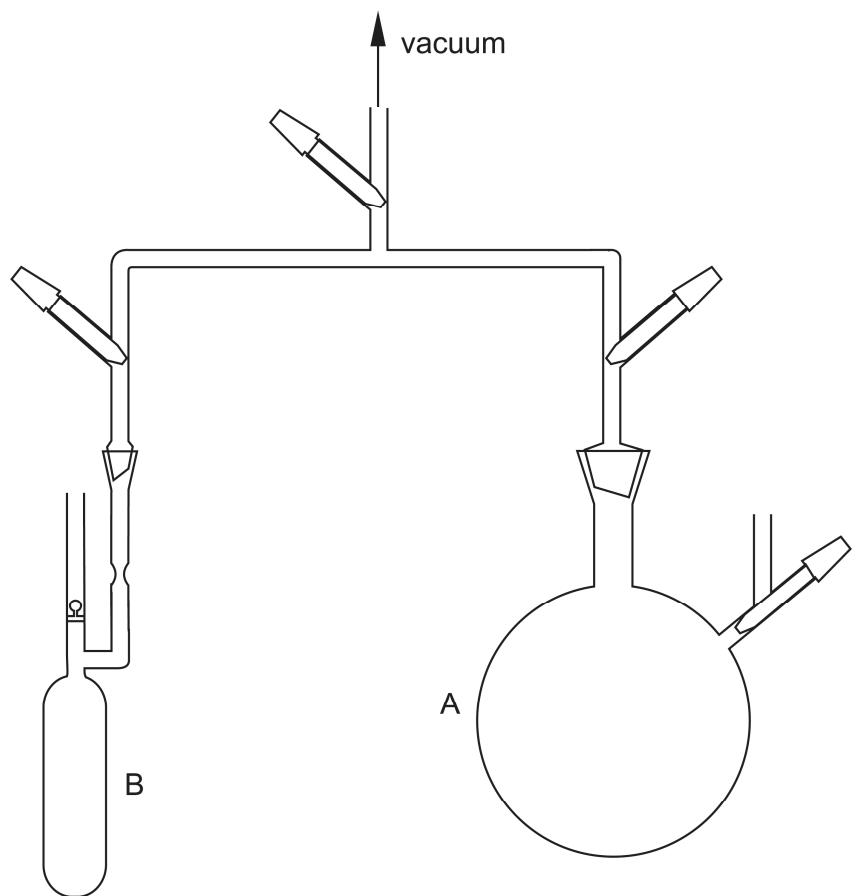

Figure 1. Apparatus for sealing solvents into ampoules over $\mathrm{Na} / \mathrm{K}$ alloy.

Fullerides Synthesis in Solution. $150.0 \mathrm{mg}\left(0.2 \times 10^{-3} \mathrm{~mol}\right)$ of grinded $\mathrm{C}_{60}$ were reacted with $93.0 \mathrm{mg}\left(0.2 \times 10^{-3} \mathrm{~mol}\right)$ of dibenzo24-crown-8 (DB24C8) and excess of metallic potassium, in form of potassium mirror, in $30 \mathrm{ml}$ of tetrahydrofurane (THF). After adding octane, the solution was used for crystallization by the modified "temperature difference" method and crystals were picked from the precipitate under oil on air.

The glassware for fullerides synthesis in solution is shown on Figure 2.

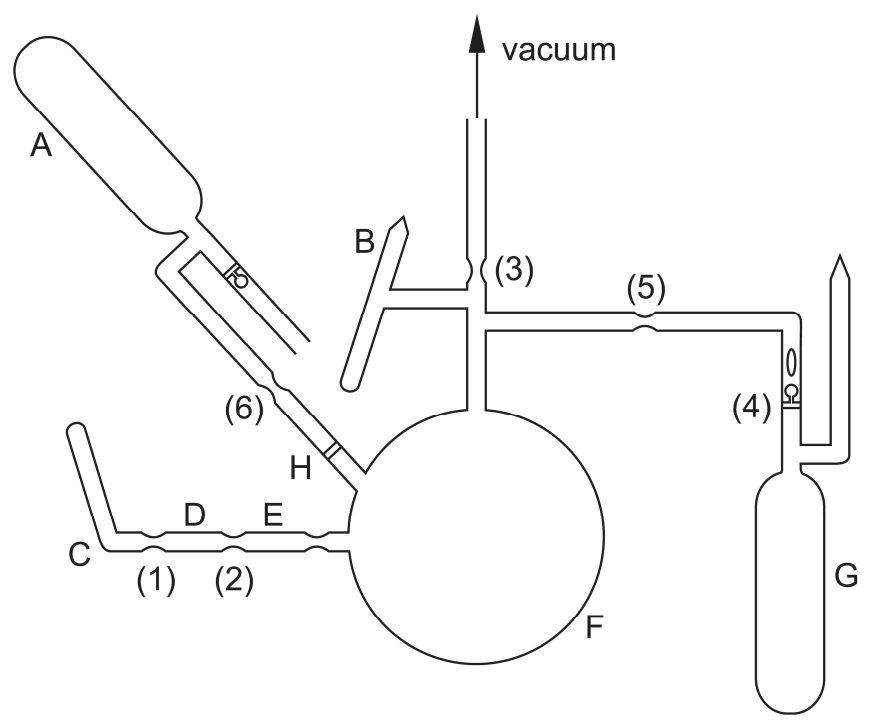

Figure 2. Scheme of the glassware for synthesis in solution.

Fullerene $\mathrm{C}_{60}$ was grinded and placed into the ampoule $A$. Crownether was placed into $B$. The open tubes through which the compounds have been introduced were sealed, the glassware evacuated and heated carefully with "cold" flame under dynamic vacuum. The system was flown with argon, and a piece of metallic potassium (excess) was placed into $C$ under argon flow. All open parts of the system were sealed and the glassware was evacuated. Potassium was distilled three times by gentle heating of the glass from $C$ to $D$, from $D$ to $E$, and, finally, from $E$ to $F$, the first two steps followed by subsequent sealing off at the constrictions (1) and (2). A silver-violet potassium "mirror" was formed on the internal surface of $F$. The system was sealed off from the vacuum at the constriction (3). The ampoule with THF (30 ml) over $\mathrm{Na} / \mathrm{K}$ alloy was cooled in liquid nitrogen for decreasing the vapour pressure inside (general procedure before breaking a breakseal on the way to an ampoule containing a solvent or a solution), and the breakseal (4) was broken. THF was distilled from $G$ into $F$ by gently chilling with liquid nitrogen. The constriction (5) was sealed off.

Some THF was condensed in $B$ by cooling it with liquid nitrogen, and the crown-ether in $B$ was dissolved. The solution of the crownether in THF was poured from $B$ to $F$ by inclining the system and shaked gently for 1-2 min. During this time the colour of THF changed from blue to yellowish. The solvent must be cold while it is known that crown ethers are being slowly decomposed by potassium [38].

The glassware was inclined, and the resulting solution mixture was filtered from the possible potassium residues in the solution through a glass filter № $3 H$ into the ampoule $A$ by chilling it with liquid nitrogen. The constriction (6) was "washed" with solvent by chilling the constriction with liquid nitrogen (general procedure before sealing off a constriction through which a solution was overflown) and sealed off. On warming to room temperature and shaking the solution in $A$ got reddish-black.

Filtering the Solution and its Separating into Small Individual Ampoules. The glassware used is presented on Figure 3. It consists of the ampoule with the solution, $A$, equipped with a breakseal and a magnet inside, a glass filter, an ampoule with a breakseal into which the solution should be filtered and small ampoules $C_{n}$. The system was checked for leakages, heated under vacuum and sealed 
off from the vacuum line at the constriction (1). The ampoule $A$ was cooled in liquid nitrogen, the breakseal (2) was broken, and the solution was filtered from $A$ to $B$ by cooling $B$ with liquid nitrogen and gently warming up $A$, if necessary. The small ampoules $C_{n}$ were filled with solution one after another; the constrictions were washed by condensing the solvent on chilling, and sealed off. Several ampoules $C_{n}$ were needed for optimizing the crystallization conditions.



Figure 3. Scheme of the glassware for filtering the solution and its separation into small individual ampoules.

Crystallization. The modified "temperature difference" method [39-42] was used for crystallization. The glassware for crystallization (Figure 4) consists of an ampoule with fulleride solution (as prepared in the previous step), $A$, an ampoule with octane over $\mathrm{Na} / \mathrm{K}$ alloy, $B$, both equipped with breakseals, a vessel for mixing the solution and the solvent, $C$, as well as ampoules for crystallization, $D_{n}$. After all the glassware has been checked for leakages and heated under vacuum, it was sealed off from the vacuum line at the constriction (1). B was cooled with liquid nitrogen, the breakseal (2) was broken, and octane was condensed into $C$ by chilling it with liquid nitrogen. (Typically, the amount of condensed octane equalled to $1 / 4$ or less of the volume of the fulleride solution, otherwise a precipitate was formed right after mixing fulleride solution and octane). $B$ was then sealed off at (3). $A$ was chilled with liquid nitrogen, the breakseal (4) was broken, and the solution was poured into $C$.

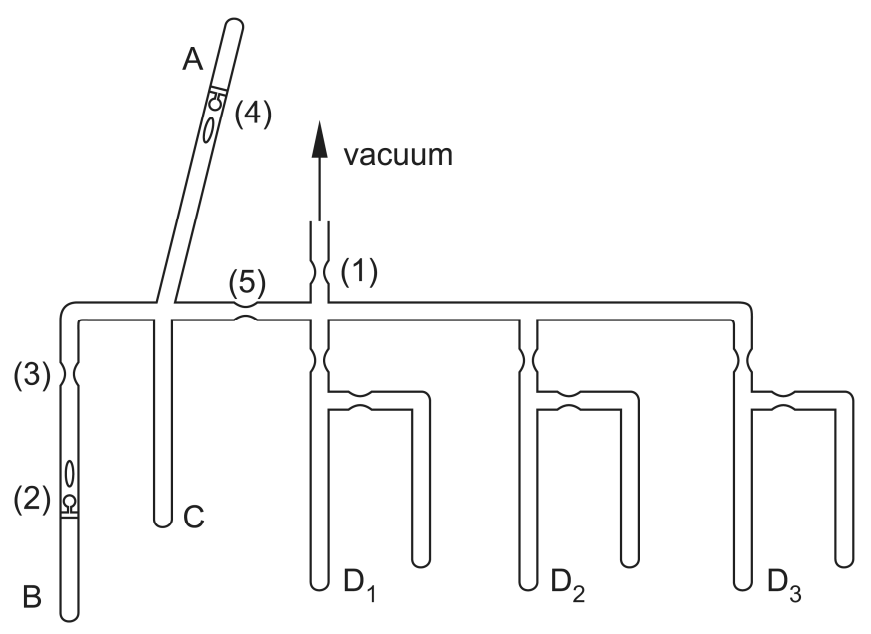

Figure 4. Scheme of the glassware for the preparation of the solution for crystallization.

The mixture in $C$ was shortly mixed and transferred to the righthand part of the glassware. The constriction (5) was washed with solvent by chilling and sealed off. The mixture was divided into ampoules $D_{n}$, each of them was subsequently sealed off at the constrictions.

The ampoules prepared as described above were placed (Figure 5) with one thigh $A$ into a programmable furnace (angle of inclination ca. 30 degrees), the other, $B$, being left at room temperature, the temperature difference between the two thighs being 2-4 degrees $\left(\mathrm{T}_{\text {furnace }}>\mathrm{RT}\right)$. Platelet-like dark violet-reddish crystals were formed on the walls of the ampoules in the solvent mixture in $A$ (the ampoule was checked regularly starting from the second day of the crystallization under the microscope for crystal formation). After crystals suitable for X-ray diffraction were formed, $A$ was sealed off at the constriction (1). Time of crystallization could take from some days to weeks, depending on the volume of the solution and the temperature difference. The inclination of the ampoule in most cases was kept from $30^{\circ}$ to $40^{\circ}$.

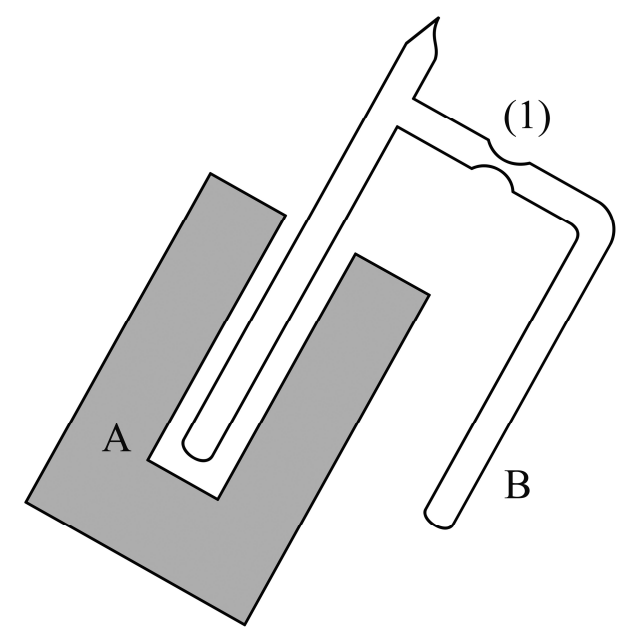

Figure 5. Crystallization by the modified "temperature difference" method.

Structure Determination. For X-ray diffraction experiments, black needle shaped crystal (Figure 6) was selected from the mother solution, transferred in a high viscous oil, and mounted onto a kapton loop (MicroMounts ${ }^{\mathrm{TM}}$, MiTeGen, Ithaca, USA), see Figure 
6 (inlay). The intensity data of the single crystal were collected with a Smart APEX II diffractometer (Bruker AXS, Karlsruhe, Germany) with Mo- $K_{\alpha}$ radiation $(0.71073 \AA$ ) at $100 \mathrm{~K}$ [43]. Data reduction was carried out with the Bruker Suite software package [44], absorption correction was applied using SADABS [45]. From systematic extinctions the polar space group $P 22_{1} 2_{1} 2$ was deduced. The structure was solved by direct methods and refined by fullmatrix least-squares fitting with the SHELXTL software package [46]. It was not possible to determine the absolute structure during the structure refinements; racemic twinning was assumed, which slightly improves the $R$-values. Experimental details on the crystallographic data and data collection are given in Table 1, atomic parameters and displacement parameters are deposited [47].



Figure 6. Crystals of $\mathrm{KC}_{60}(\mathrm{THF})_{5} \cdot(\mathrm{THF})_{2}$ under the microscope (main), and needle mounted on a cryo-loop covered by oil for measurement at the single crystal diffractometer (inlay).

Table 1. Crystallographic data for $\mathrm{KC}_{60}(\mathrm{THF})_{5}(\mathrm{THF})_{2}$.

\begin{tabular}{ll}
\hline Chemical formula & $\mathrm{C}_{84} \mathrm{H}_{48} \mathrm{KO}_{6}$ \\
\hline Temperature $/ \mathrm{K}$ & $100(2)$ \\
Formula weight & 1192.32 \\
Crystal system & orthorhombic \\
Space group (no.), $Z$ & $P 2_{1} 2_{1} 2(18), 4$ \\
Lattice constants $/ \AA$ & $a=17.802(5)$ \\
& $b=30.085(9)$ \\
& $c=9.863(3)$ \\
Volume $/ \AA^{3}$ & $V=5283(3)$ \\
Density $\left(\right.$ calculated) $/ \mathrm{g} \mathrm{cm}{ }^{-3}$ & $\rho=1.499$ \\
Crystal size $/ \mathrm{mm}^{3}$ & $0.03 \times 0.05 \times 0.21$ \\
Colour & black \\
Diffractometer & $\mathrm{Smart} \mathrm{APEX} \mathrm{II,} \mathrm{Bruker} \mathrm{AXS}$ \\
$\mathrm{X}$-ray radiation, $\lambda / \AA$ & MoK $\alpha, 0.71073$ \\
Monochromator & graphite \\
Absorption coefficient $\mu / \mathrm{mm}^{-1}$ & 0.170 \\
$2 \theta$ range $/{ }^{\circ}$ & 3.54 to 41.80 \\
Index range & $-17 \leq h \leq 17,-30 \leq k \leq 30$, \\
& $-9 \leq l \leq 9$ \\
Absorption correction & multi-scan, SADABS $[45]$ \\
Reflections collected & 26190 \\
Independent reflections, $R_{\text {int }}$ & $5563,0.087$ \\
No. of parameters & 822 \\
$R_{1}\left[F^{2}>2 \sigma\left(F^{2}\right)\right], w R\left(\mathrm{~F}^{2}\right)$ & $0.069,0.191$ \\
Absolute structure parameter & $0.59(12)$ \\
$\Delta \rho_{\text {max }}, \Delta \rho_{\text {min }} / \mathrm{e} \AA^{-3}$ & $0.338,-0.260$ \\
\hline &
\end{tabular}

The positions of the potassium atom and all 60 carbon atoms from the fullerene could be taken from the structure solution, and the missing $\mathrm{O}$ - and $\mathrm{C}$-atoms belonging to the THF molecules were found from the difference Fourier map. The positions of the hydrogen atoms were calculated geometrically, and their isotropic displacement parameters were restrained to 1.2 times the value of the respective attached carbon atom. All non hydrogen atoms were treated with anisotropic displacement parameters. The $\mathrm{C}_{60}$ molecule was completely ordered, while high values for the parameters of anisotropic thermal motion were observed for all THF molecules coordinated to potassium, and they can alternatively be described with a split-model comprising two orientations for each THF. There were problems in locating the exact positions of the uncoordinated solvent THF molecules. Their centres coincide with special positions $(2 a, 00 z$ and $2 b, 01 / 2 z)$ and large anisotropic displacement parameters were observed [47]. Carefully examining the diffraction data revealed very weak super structure reflections, indicating a $5 \times 1 \times 2$ super cell. This enlargement of the unit cell might be caused by a special kind of modulation of the THF molecules. However, due to the weak super cell intensity data, which could neither be overcome using $\mathrm{Cu}-\mathrm{K}_{\alpha}$ radiation, it was not possible to find and refine a fully ordered structure model in $(3+1) \mathrm{D}$ space.

\section{Results and Discussion}

The title compound $\mathrm{KC}_{60}(\mathrm{THF})_{5}(\mathrm{THF})_{2}$ has been obtained along the "break-and-seal" procedure by reacting fullerene $\mathrm{C}_{60}$ with potassium and dibenzo-24-crown-8 in tetrahydrofurane as black needles, which are sensitive to air. Interestingly, crown-ether was not incorporated as a ligand coordinating potassium, and the crystal structure consists of metal atoms, fullerene and solvent molecules THF, exclusively.

$\mathrm{KC}_{60}(\mathrm{THF})_{5} \cdot(\mathrm{THF})_{2}$ crystallizes in the orthorhombic space group $P 2{ }_{1} 22$ (no. 18) with four formula units per unit cell (Figure 7). The structure contains one potassium atom per one $\mathrm{C}_{60}$ unit, therefore, the fulleride is an anion-radical $\mathrm{C}_{60}{ }^{-}$. Each potassium atom is coordinated by five THF molecules acting as monodentate ligands forming a square pyramid with $d(\mathrm{~K}-\mathrm{O}) \approx 2.7 \AA$ (Figure 8). The coordination sphere is completed by a hexagon of the fullerene, with an octahedral coordination resulting for the potassium atom. A similar coordination of potassium and THF molecules was observed before in ${ }_{\infty}^{1}\left[\left\{\mathrm{~K}(\mathrm{THF})_{5}\right\}_{2}\left(\mathrm{C}_{60}\right)\left\{\mu-\mathrm{K}(\mathrm{THF})_{4}\right\}\right] \quad[48]$, with potassium to THF oxygen distances ranging from $2.61 \AA$ to $2.74 \AA$. Two more solvent molecules are not coordinating and are located with their barycentres at special positions.

$\mathrm{C}_{60}{ }^{-}$and $\mathrm{K}^{+}$form an ion pair, with potassium having shortest contact to three contiguous carbon atoms from a hexagon of $\mathrm{C}_{60}$ at $3.36,3.21$ and $3.43 \AA$ (Figure 8). The $\mathrm{K}-$ $\mathrm{C}$ distances to the three more remote carbon atoms are 3.70 $\AA$, $3.76 \AA$ and $3.90 \AA$. Thus, $\mathrm{C}_{60}$ clearly has a hapticity of three, corresponding to $\left[\mathrm{K}\left(\eta^{3}-\mathrm{C}_{60}\right)\left(\eta^{1}-\mathrm{THF}\right)_{5}\right] \cdot(\mathrm{THF})_{2}$. In this respect, the title compound differs evidently from ${ }_{\infty}^{1}\left[\left\{\mathrm{~K}(\mathrm{THF})_{5}\right\}_{2}\left(\mathrm{C}_{60}\right)\left\{\mu-\mathrm{K}(\mathrm{THF})_{4}\right\}\right]$, mentioned above, where all six $\mathrm{C}$-atoms from one hexagon of the $\mathrm{C}_{60}$-molecule are coordinated to potassium $\left(d\left(\mathrm{~K}-\mathrm{C}_{60}\right)=3.29-3.44 \AA\right)$ [48]. A similar $\eta^{3}$-coordination between fullerides and alkali metal cations has been recently reported for $[\mathrm{Rb}$ (benzo[18]crown$6)]_{3}\left[\eta^{3}-\mathrm{C}_{60}\right]\left(\mathrm{C}_{7} \mathrm{H}_{8}\right)-\left(\mathrm{C}_{3} \mathrm{H}_{7} \mathrm{NO}\right)_{4.5}[48]$. 


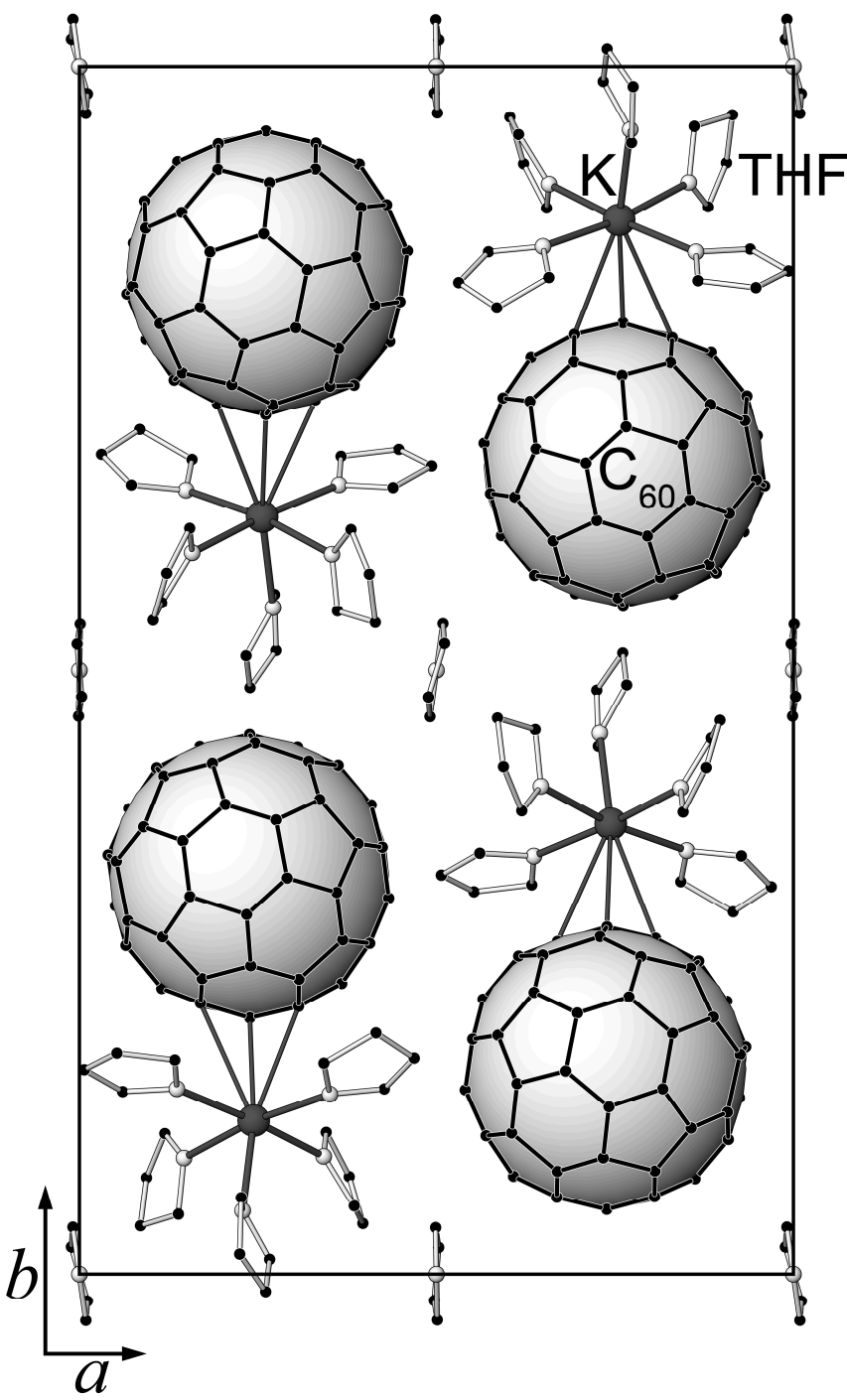

Figure 7. Projection of the crystal structure of $\mathrm{KC}_{60}(\mathrm{THF})_{5} \cdot(\mathrm{THF})_{2}$ along [ $\left[\begin{array}{lll}0 & 0 & 1\end{array}\right]$, with margins of the unit cell given. Hydrogen atoms are omitted.

The ion pairs as described above are arranged in a way that the hydrogen bearing parts and the aromatic (fullerene) parts, respectively, flock together. This is a characteristic feature frequently encountered in crystal chemistry; the driving force is the optimization of the weak intermolecular interactions in the sense of "similar attracts similar".

$\mathrm{K}^{+} \mathrm{C}_{60}{ }^{-}$ion pairs thus form corrugated layers in the $a-c$ crystallographic plane. The interlayer separation is $15.06 \AA$ ( $n$ in Figure 9), the intralayer center-to-center fullerene distances being $10.12 \AA$ ( $m$ in Figure 9 ) and $9.86 \AA$ along the $c$-axis. The layers are slightly shifted by $0.66 \AA$ one from the other in the $a-c$ plane.

This way one of the objectives of our current project has been accomplished, namely, to create low-dimensional fulleride partial structures. As illustrated in Figure 9 and mentioned above, the shortest interfulleride separations occur in layers parallel to $\left(\begin{array}{lll}0 & 1 & 0\end{array}\right)$.

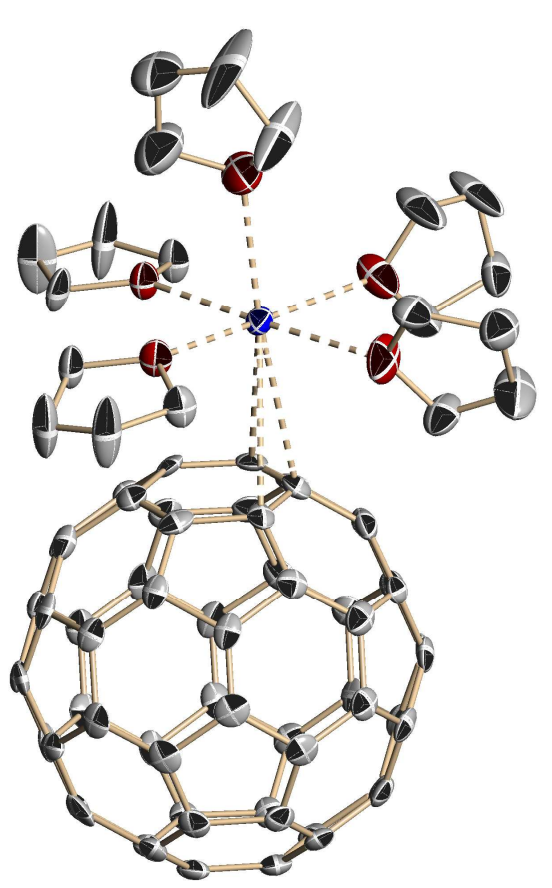

Figure 8. Fragment of the crystal structure showing the coordination of the potassium atom by the solvent molecules and fullerene cage (dotted lines). Displacement ellipsoids are drawn at the $50 \%$ probability level, hydrogen atoms are omitted. Colour code: carbon (grey), oxygen (red), potassium (blue).

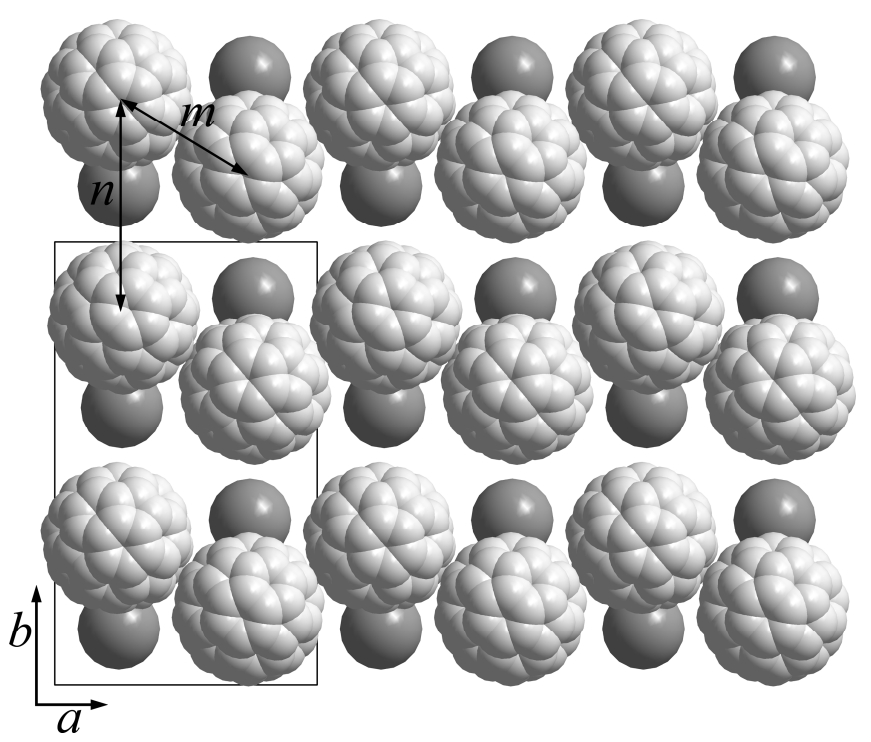

Figure 9. Space-filling model of the structure displaying van der Waals radii of fulleride anions and potassium cations, solvent molecules are omitted. $\mathrm{K}^{+}-\mathrm{C}_{60}{ }^{-}$ion pairs form layers in the $a-c$ crystallographic plane. The interlayer separation is $15.06 \AA(n)$, the intralayer center-to-center fullerene distances are $10.12 \AA(\mathrm{m})$ and $9.86 \AA$ along the $c$-axis (not shown on the picture).

In Figure 10 a histogram is shown, representing the spread of the $\mathrm{C}-\mathrm{C}$ distances in $\mathrm{C}_{60}{ }^{-}$as found by refinement of all positions involved individually and without using constraints. One can clearly identify a dip in the distribution separating the shorter bonds between edge sharing hexagons (6:6 bonds) from those shared by hexagons and pentagons (6:5 bonds). 


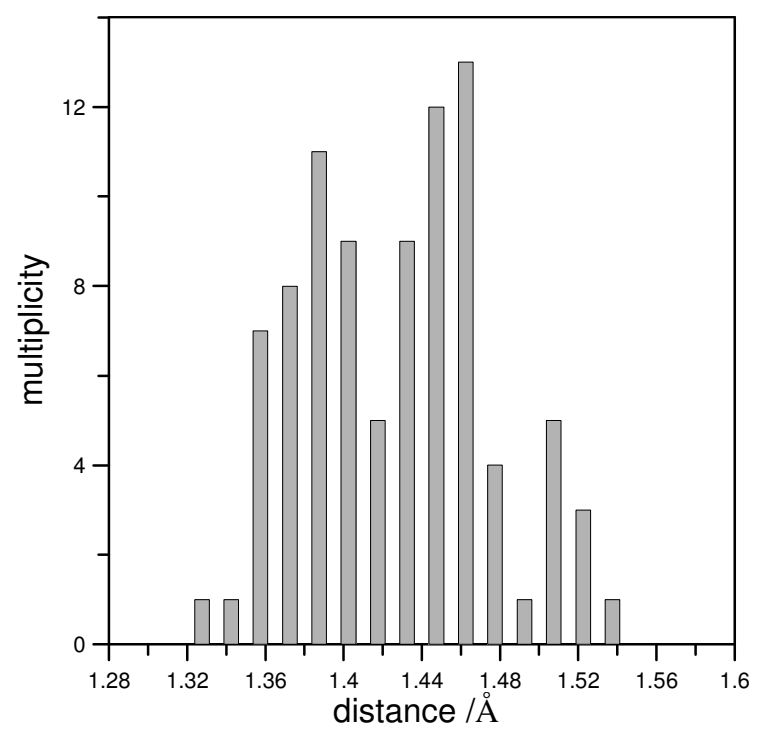

Figure 10. $\mathrm{C}-\mathrm{C}$ bond length distribution within the fulleride anion in $\mathrm{KC}_{60}(\mathrm{THF})_{5} \cdot(\mathrm{THF})_{2}$

Because of the rather high e.s.d.'s it has not been possible to identify some more detailed systematics in the bond lengths' distribution, potentially indicating some localization of the negative charge on the surface of the fullerene.

\section{Acknowledgments}

We thank Dr. Konstantin Amsharov for helpful discussions.

\section{References}

[1] J. de Vries, H. Steger, B. Kamke, C. Menzel, B. Weisser, W. Kamke, I.V. Hertel, Chem. Phys. Lett. 1992, 188, 159.

[2] C. A. Reed, R. D. Bolskar, Chem. Rev. 2000, 100, 1075.

[3] D. L. Lichtenberger, K. W. Nebesny, C. D. Ray, D. R. Huffmann, L. D. Lamb, Chem. Phys. Lett. 1991, 176, 203.

[4] A. Hönnerscheid, L. van Wüllen, M. Jansen, J. Chem. Phys. 2001, 115,7161 .

[5] A. Hönnerscheid, R. Dinnebier, M. Jansen, Acta Cryst., Sect. B: Struct. Sci. 2002, 58, 482.

[6] A. Hönnerscheid, L. van Wüllen, R. Dinnebier, M. Jansen, J. Rahmer, M. Mehring, J. Phys. Chem. Chem. Phys. 2004, 6 , 2454.

[7] D. V. Konarev et al., J. Am. Chem. Soc. 2002, 124, 8520.

[8] D. V. Konarev, S. S. Khasanov, G. Saito, A. Otsuka, Y. Yoshida, R. N. Lyubovskaya, J. Am. Chem. Soc. 2003, 125, 10074.

[9] D. V. Konarev, S. S. Khasanov, A. Y. Kovalevsky, G. Saito, A. Otsuka, R. N. Lyubovskaya, Dalton Trans. 2006, 3716.

[10] P. W. Stephens, G. Bortel, G. Faigel, M. Tegze, A. Janossy, S. Pekker, G. Pszlany, L. Forro, Nature 1994, 370, 636.

[11] G. Oszlányi, G. Baumgartner, G. Faigel, L. Forró, Phys. Rev. Lett. 1997, 78, 4438.

[12] S. Margadonna, K. Prassides, K. D. Knudsen, M. Hanfland, M. Kosaka, K. Tanigaki, Chem. Mater. 1999, 11, 2960.
[13] H. Brumm, E. Peters, M. Jansen, Angew. Chem. 2001, 113, 2117; Angew. Chem. Int. Ed. Engl. 2001, 40, 2069.

[14] U. Wedig, H. Brumm, Martin Jansen, Chem. Eur. J. 2002, 8, 2769.

[15] M. Panthöfer, U. Wedig, H. Brumm, M. Jansen, Solid State Sci. 2004, 6, 619 .

[16] P. Paul, Z. Xie, R. Bau, P. D. W. Boyd, C. A. Reed, J. Am. Chem. Soc. 1994, 116, 4145.

[17] P. D. W. Boyd, P. Bhyrappa, P. Paul, J. Stinchcombe, R. D. Bolskar, Y. P. Sun, C. A. Reed, J. Am. Chem. Soc. 1995, 117, 2907.

[18] K. Himmel, M. Jansen, Inorg. Chem. 1998, 37, 3437.

[19] A. F. Hebard, M. J. Rosseinsky, R. C. Haddon, D. W. Murphy, S. H. Glarum, T. T. M. Palstra, A. P. Ramirez, A. R. Kortan, Nature 1991, 350, 600.

[20] M. J. Rosseinsky, Chem. Mater. 1998, 10, 2665.

[21] P. M. Allemand, K. C. Khemani, A. Koch, F. Wudl, K. Holczer, S. Donovan, G. Grüner, J. D. Thompson, Science 1991, 253, 301.

[22] P. W.Stephens, D. Cox, J. W. Lauher, L. Mihaly, J. B. Wiley, P.-M. Allemand, A. Hirsch, K. Holczer, Q. Li, J. D. Thompson, F. Wudl, Nature 1992, 355, 331.

[23] K. Himmel, M. Jansen, Chem. Commun. 1998, 11, 1205.

[24] K. Himmel, M. Jansen, Z. Anorg. Allg. Chem. 1998, 624, 1.

[25] K. Himmel, M. Jansen, Eur. J. Inorg. Chem. 1998, 1183.

[26] H. Brumm, M. Jansen, Z. Anorg. Allg. Chem. 2001, 627, 1433.

[27] Th. F. Fässler, A. Spiekermann, M. E. Spahr, R. Nesper, Angew. Chem. 1997, 109, 502; Angew. Chem. Int. Ed. Engl. 1997, 36, 486.

[28] Th. F. Fässler, R. Hoffmann, S. Hoffmann, M. Wörle, Angew. Chem. 2000, 112, 2170; Angew. Chem. Int. Ed. Engl. 2000, 39, 2091.

[29] S. D. Hoffmann, Th. F. Fässler, Z. Naturforsch., 2004, 59b, 1579.

[30] M. B. Boeddinghaus, M. Salzinger, Th. F. Fässler, Chem. Eur. J. 2009, 15, 3261.

[31] D. V. Konarev, S. S. Khasanov, R. N. Lyiubovskaya, Russ. Chem. Bull., Int. Ed. 2007, 56, 371.

[32] J. L. Dye, C. W. Andrews, S. E. Mathews, J. Phys. Chem. 1975, 79, 3065 .

[33] J. L. Dye, Angew. Chem. 1979, 91, 613; Angew. Chem. Int. Ed. Engl. 1979, 18, 587.

[34] J .L. Dye, J. Phys. Chem. 1980, 84, 1084.

[35] J. L. Dye, J. Phys. Chem. 1984, 88, 3842.

[36] M. Szwarc, Carbanions, Living Polymers and Electron Transfer Process, Wiley-Interscience, New York 1968.

[37] D. F. Shriver, The Manipulation of Air-sensitive Compounds. McGraw-Hill, Book Company, New York 1969.

[38] Z. Jedlinski, A. Stolarchewicz, Z. Grobelny, Makromol. Chem. 1986, 187, 795.

[39] H. Arend, R. Perret, H. Wüst, P. Kerkoc, J. Cryst. Growth 1986, $74,321$.

[40] W. S. Wang, J. Hulliger, H. Arend, Ferroelectrics 1989, 92 , 113.

[41] J. Hulliger, Angew. Chem. 1994, 106, 151; Angew. Chem. Int. Ed. Engl. 1994, 33, 143.

[42] O. König, P. Rechsteiner, B. Trusch, C. Andreoli, J. Hulliger, J. Appl. Cryst. 1997, 30, 507. 
1

[43] G. Cakmak, J. Nuss, M. Jansen, Z. Anorg. Allg. Chem. 2009, 635, 631.

[44] Bruker Suite, Version 2008/3, Bruker AXS Inc., Madison, USA 2008.

[45] G. M. Sheldrick, SADABS - Bruker AXS area detector scaling and absorption, Version 2008/1, University of Göttingen, Germany 2008.

[46] G. M. Sheldrick, Acta Crystallogr., Sect. A: Found. Crystallogr. 2008, 64, 112.

[47] CCDC XY1234 contains the supplementary crystallographic data for this paper. These data can be obtained free of charge from The Cambridge Crystallographic Data Centre via www.ccdc.cam.ac.uk/data_request/cif.

[48] C. Janiak, S. Mühle, H. Hemling. Polyhedron 1996, 15, 1559.

Received: ((will be filled in by the editorial staff)) Published online: ((will be filled in by the editorial staff)) 




Apparatus for sealing solvents into ampoules over $\mathrm{Na} / \mathrm{K}$ alloy. $120 \times 126 \mathrm{~mm}(600 \times 600 \mathrm{DPI})$ 




Scheme of the glassware for synthesis in solution. $120 \times 100 \mathrm{~mm}(600 \times 600 \mathrm{DPI})$ 


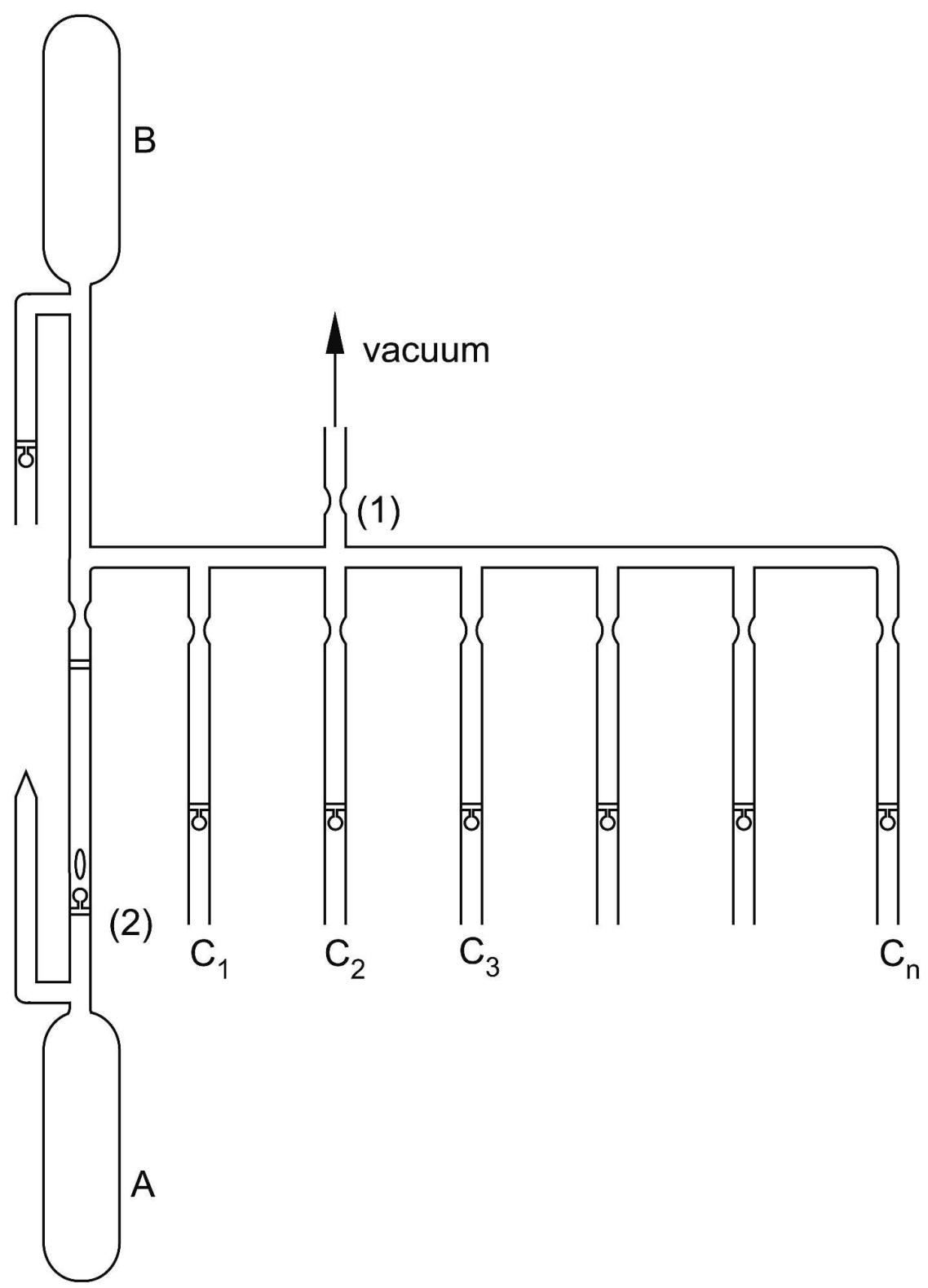

Scheme of the glassware for filtering the solution and its separation into small individual ampoules. $120 \times 168 \mathrm{~mm}(600 \times 600 \mathrm{DPI})$ 


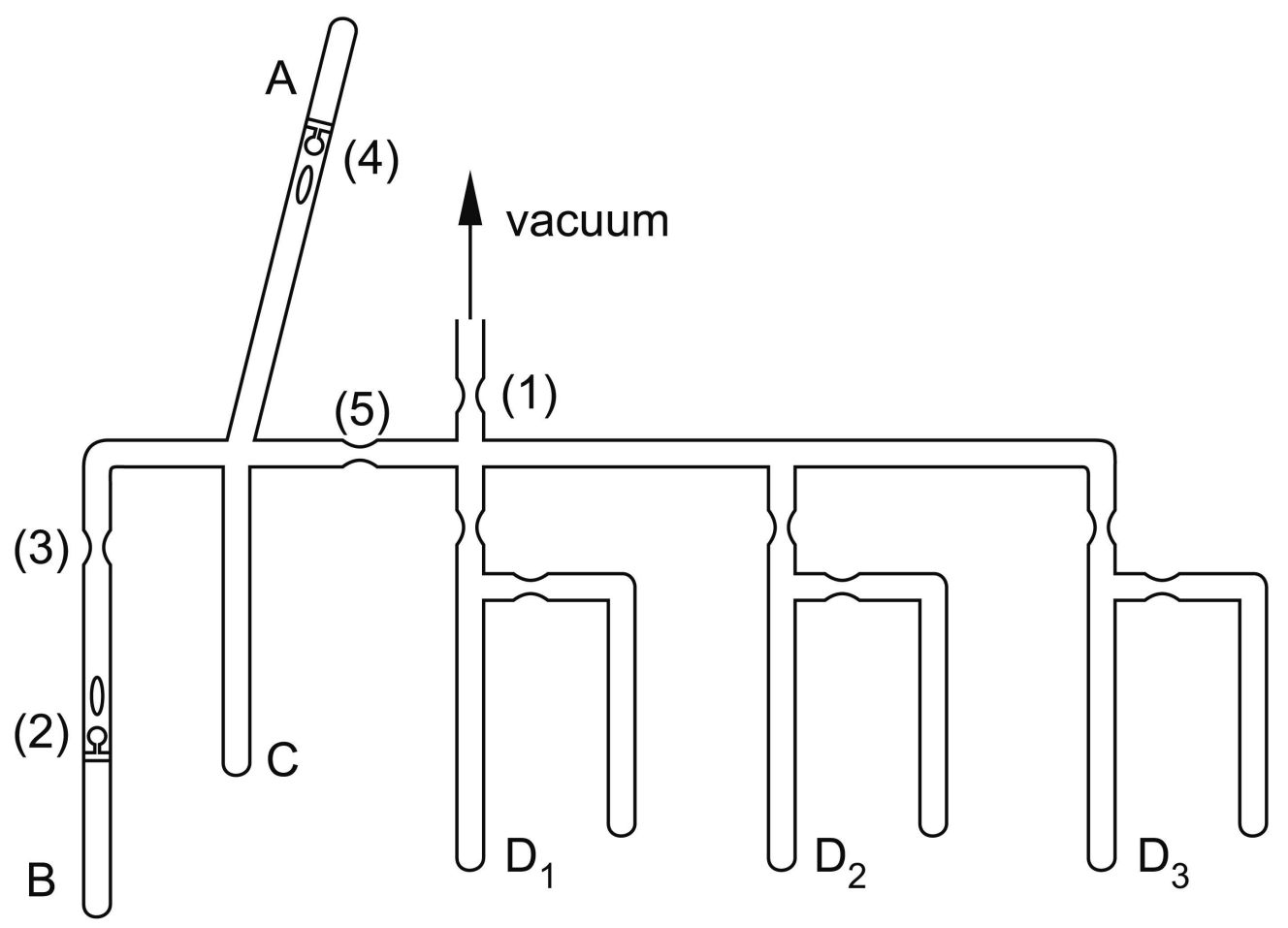

Scheme of the glassware for the preparation of the solution for crystallization. $120 \times 85 \mathrm{~mm}(600 \times 600 \mathrm{DPI})$ 


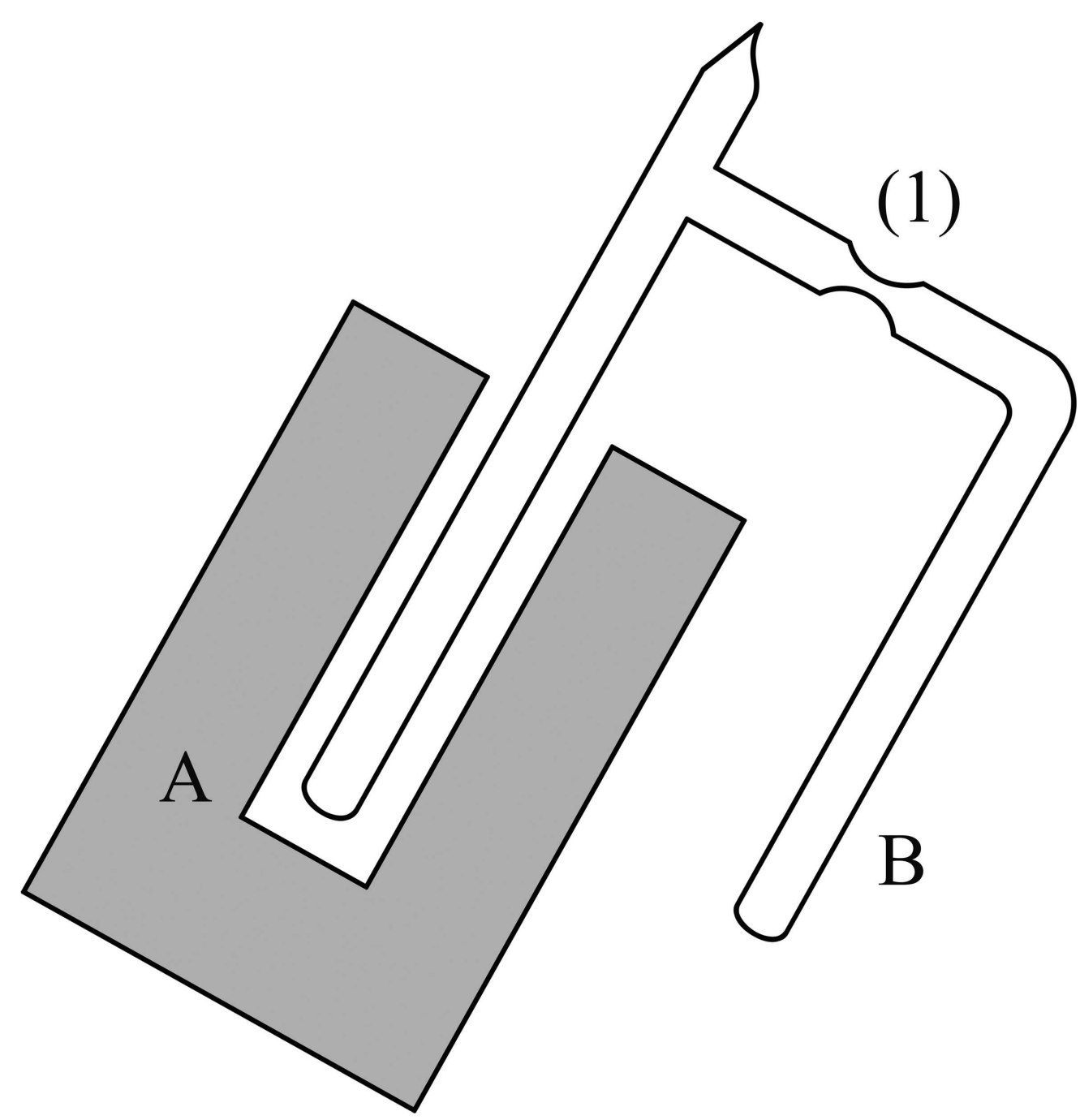

Crystallization by the modified "temperature difference" method. $100 \times 103 \mathrm{~mm}(600 \times 600 \mathrm{DPI})$ 


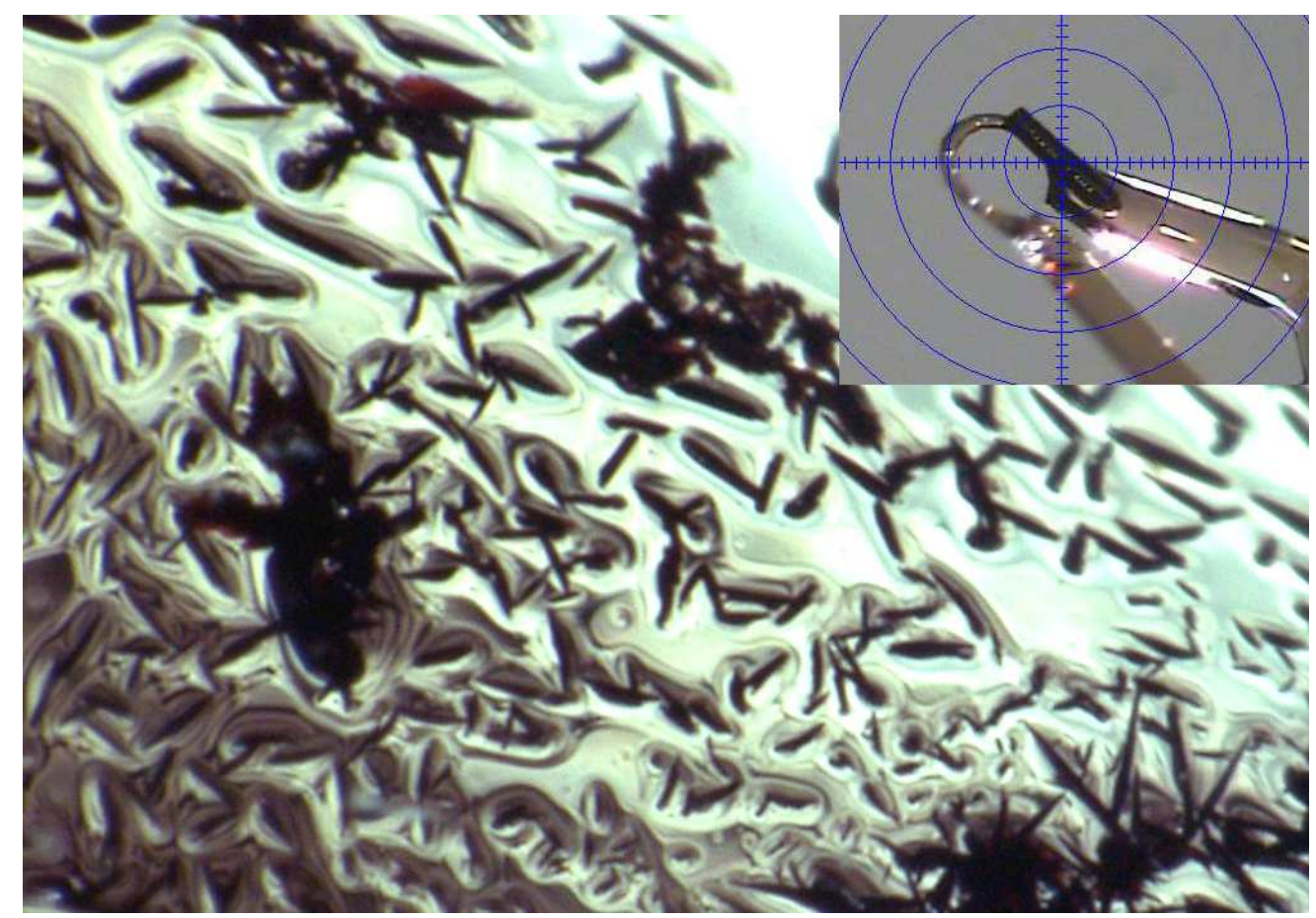

Crystals of $\mathrm{KC}_{60}(\mathrm{THF})_{5} \cdot(\mathrm{THF})_{2}$ under the microscope (main), and needle mounted on a cryo-loop covered by oil for measurement at the single crystal diffractometer (inlay). $86 \times 60 \mathrm{~mm}$ (300 x 300 DPI) 


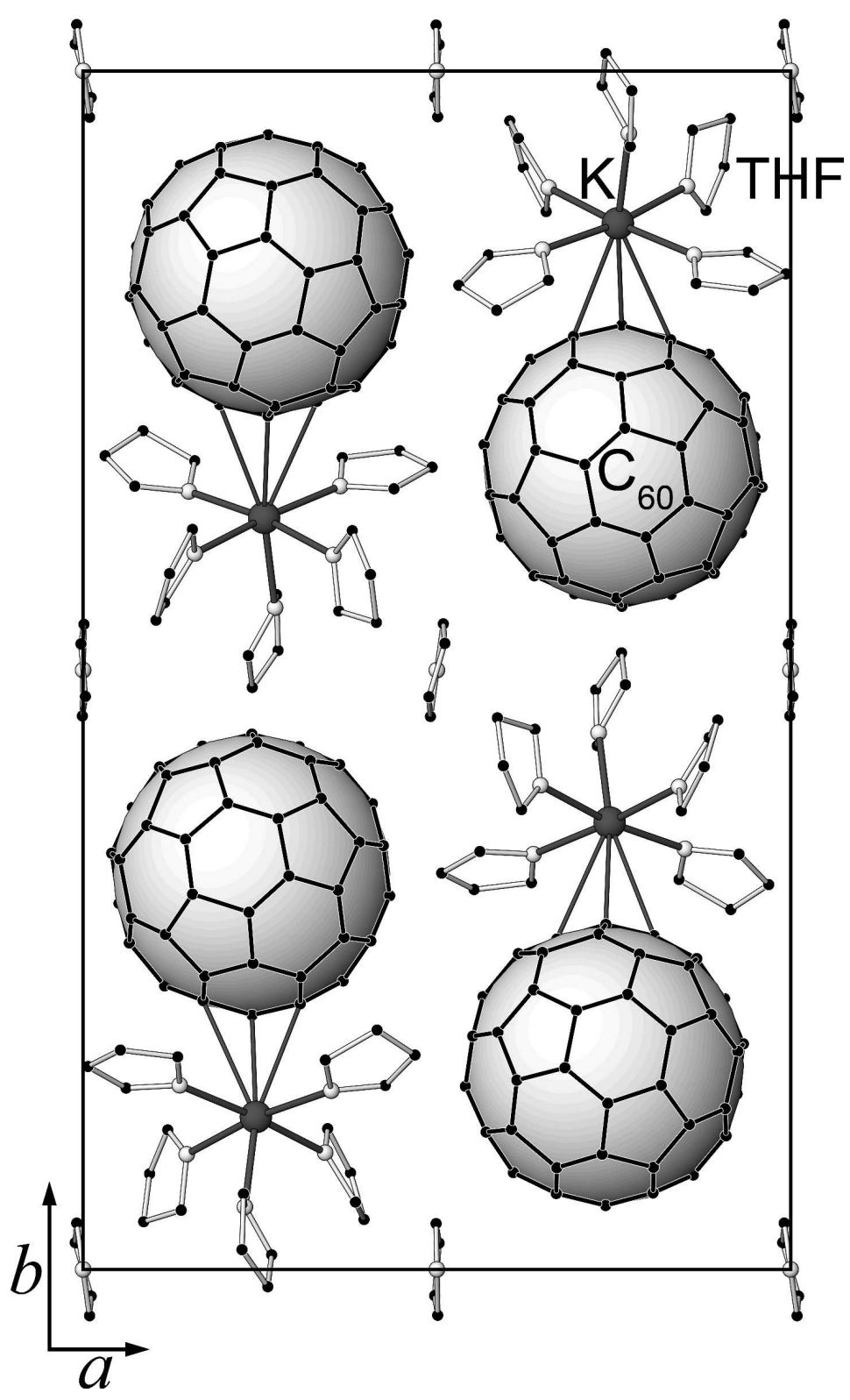

Projection of the crystal structure of $\mathrm{KC}_{60}(\mathrm{THF})_{5}(\mathrm{THF})_{2}$ along $\left[\begin{array}{lll}0 & 0 & 1\end{array}\right]$, with margins of the unit cell given. Hydrogen atoms are omitted. $123 \times 202 \mathrm{~mm}(600 \times 600$ DPI $)$ 


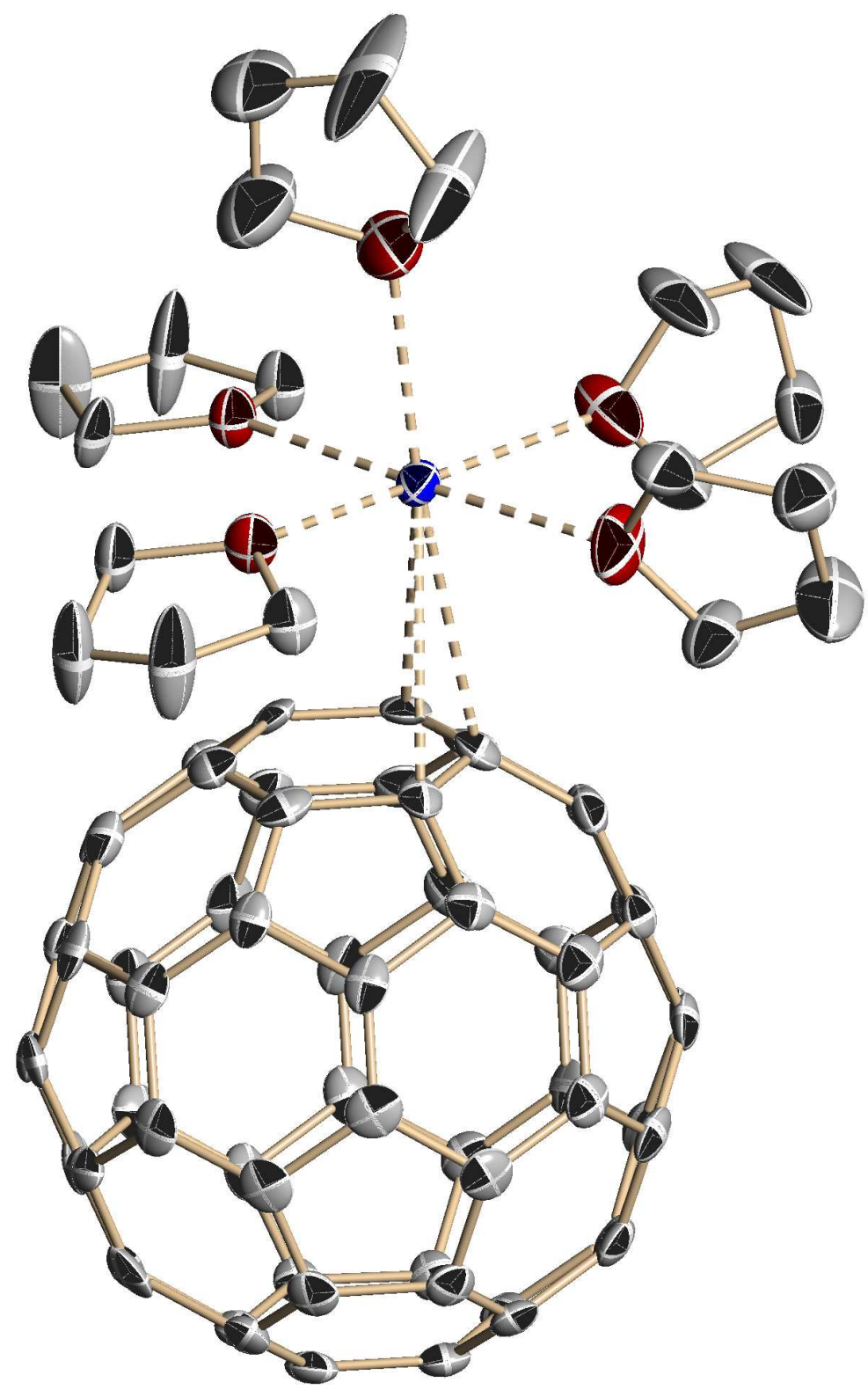

Fragment of the crystal structure showing the coordination of the potassium atom by the solvent molecules and fullerene cage (dotted lines). Displacement ellipsoids are drawn at the $50 \%$ probability level, hydrogen atoms are omitted. Colour code: carbon (grey), oxygen (red), potassium (blue).

$100 \times 162 \mathrm{~mm}(300 \times 300 \mathrm{DPI})$ 




Space-filling model of the structure displaying van der Waals radii of fulleride anions and potassium cations, solvent molecules are omitted. $\mathrm{K}^{+}-\mathrm{C}_{60} 0^{-}$ion pairs form layers in the $a-c$ crystallographic plane. The interlayer separation is $15.06 \AA(n)$, the intralayer center-to-center fullerene distances are $10.12 \AA(m)$ and $9.86 \AA$ along the $c$-axis (not shown on the picture). $120 \times 101 \mathrm{~mm}(600 \times 600 \mathrm{DPI})$ 


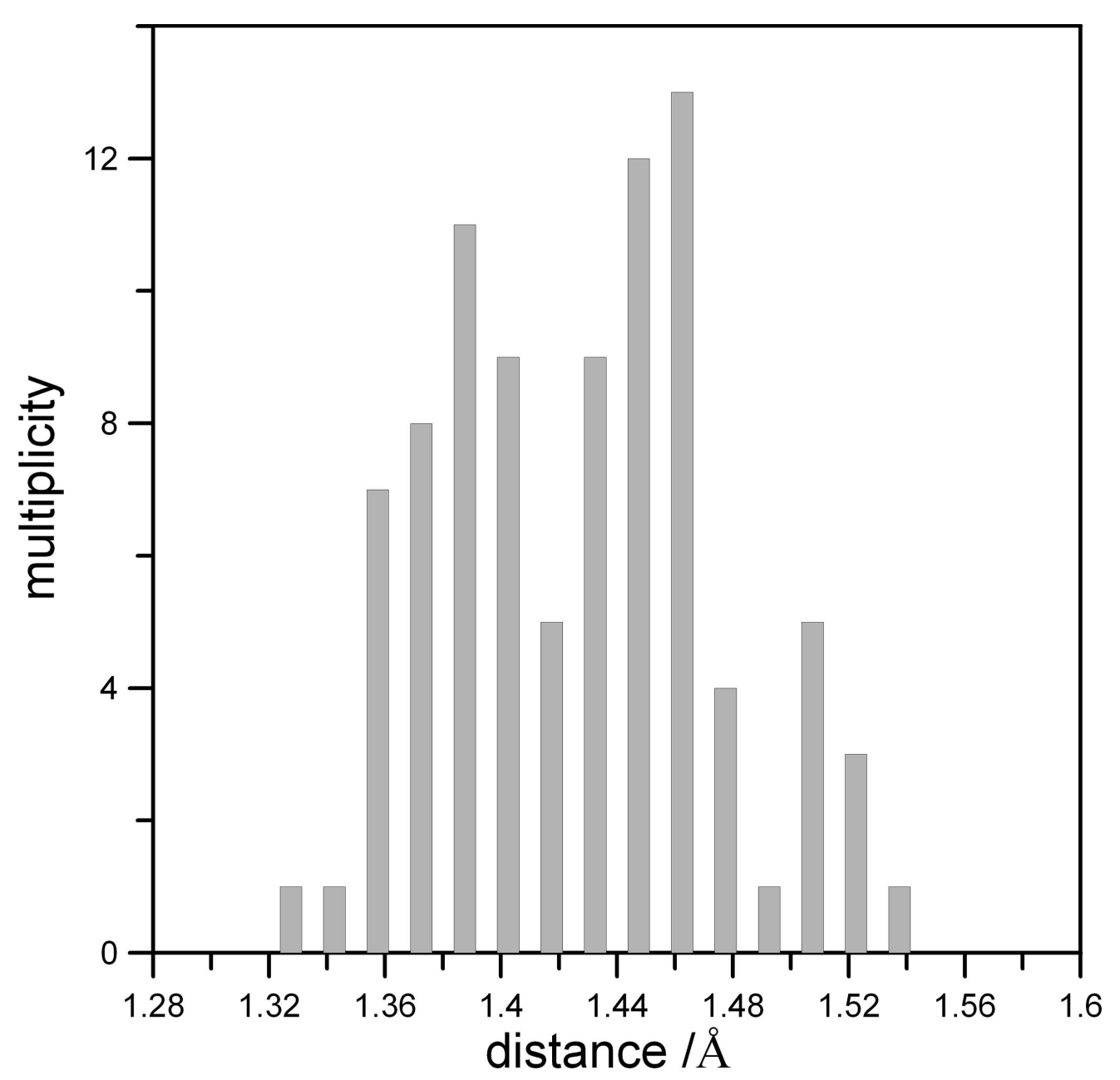

$\mathrm{C}-\mathrm{C}$ bond length distribution within the fulleride anion in $\mathrm{KC}_{60}(\mathrm{THF})_{5} \cdot(\mathrm{THF})_{2}$. $118 \times 114 \mathrm{~mm}(600 \times 600 \mathrm{DPI})$ 